\title{
FAKTOR SOSIODEMOGRAFI DAN PERILAKU PENCEGAHAN GIGITAN NYAMUK TERHADAP PERILAKU PEMBERANTASAN SARANG NYAMUK DI INDONESIA: ANALISIS LANJUT DATA RISKESDAS 2018
}

\author{
Sociodemography Factors and Mosquito Bite Prevention Behaviours Toward \\ Mosquito Nests Eradication (PSN) Actions In Indonesia: Analysis of Riskesdas 2018 \\ Data
}

\author{
Asep Hermawan ${ }^{1}$, Miko Hananto ${ }^{1}$ \\ ${ }^{1}$ Puslitbang Upaya Kesehatan Masyarakat, Badan Litbang Kesehatan Kemenkes RI \\ Email: kang.asep007@gmail.com
}

Diterima: 9 April 2020; Direvisi: 23 Juni 2020; Disetujui: 23 September 2020

\begin{abstract}
The High morbidity of dengue requires effective and efficient prevention efforts. Breaking the chain of transmission through the eradication of mosquito nests (PSN) is a way that is believe an effective and efficient in controlling dengue. However, a nation-wide study shows that PSN has not been fully implemented in Indonesia. The aim of study was to describe the relations between sociodemographic factors and mosquito bite prevention behaviour of PSN action in Indonesia, using Riskesdas 2018 data. The Population was households in Indonesia with samples as much as 262,917. The dependent variable is PSN actions and the independent variables are age group, occupation, education level, urban and rural areas as well as mosquito bite prevention practice by households and individuals. Data were analyzed using multiple logistic regression. The result was shown that the age group, education, occupation of the head of the household (KRT) and housewife (IRT) (P value <0.05) arean important variables that was influenced PSN action in Indonesia. In multiple logistic regression test, the influential variables are age group, education level, type of work, using mosquito repellent (spray / mosquito coil/ electric), the mosquito netting installed at ventilation house, sleep used insecticide-treated mosquito nets $<3$ years, repellent / bite-preventing materials, and the electric mosquito rackets. The variable that has the biggest influence is the larvasidation of the water reservoir. To preserved of PSN implementation continuously, PSN campaigns can be carried out at various age levels, education levels and occupations.
\end{abstract}

Keywords: Eradication of mosquito nests, sociodemography, dengue, and mosquito bites

\begin{abstract}
ABSTRAK
Morbiditas dengue yang tinggi memerlukan upaya pencegahan yang efektif dan efisien. Memutus rantai penularan melalui pemberantasan sarang nyamuk (PSN) merupakan salah satu cara yang dipercaya efektif dan efisien dalam pengendalian dengue saat ini. Namun, sebuah penelitian berskala nasional menunjukkan bahwa PSN belum sepenuhnya dilaksanakan di Indonesia. Artikel ini bertujuan untuk menggambarkan hubungan faktor sosiodemografi dan praktek pencegahan gigitan nyamuk terhadap perilaku PSN di Indonesia, dengan menggunakan data Riskesdas 2018. Populasi adalah rumah tangga di Indonesia dengan sampel 262.917 rumah tangga. Variabel dependen adalah perilaku PSN dan variabel independen adalah kelompok usia, pekerjaan, tingkat pendidikan, wilayah perkotaan dan perdesaan serta praktek pencegahan gigitan nyamuk oleh rumah tangga dan individu. Data dianalisis menggunakan regresi logistik. Hasil analisis menunjukan bahwa kelompok umur, pendidikan, pekerjaan kepala rumah tangga (KRT) dan ibu rumah tangga (IRT) (nilai $\mathrm{P}<0,05$ ) merupakan variabel penting yang mempengaruhi perilaku PSN di Indonesia. Pada uji regresi logistik, variabel berpengaruh adalah kelompok umur, tingkat pendididikan, jenis pekerjaan, menggunakan obat nyamuk (semprot /bakar/ elektrik, ventilasi rumah dipasang kasa nyamuk, tidur menggunakan kelambu berinsektisida $<3$ tahun, repelen/bahan pencegah gigitan, dan raket nyamuk elektrik. Pengaruh terbesar adalah larvasidasi penampungan air. Untuk menjaga kesinambungan pelaksanaan PSN, kampanye PSN dapat dilakukan pada berbagai tingkatan usia, pendidikan dan pekerjaan.
\end{abstract}

Kata kunci: Pemberantasan sarang nyamuk, sosiodemografi, dengue, pencegahan gigitan nyamuk 


\section{PENDAHULUAN}

Penyakit Demam Berdarah Dengue (DBD) merupakan salah satu masalah kesehatan masyarakat di Indonesia dengan jumlah penderita yang cenderung meningkat dan penyebarannya semakin luas (Kemenkes RI, 2011). Sejak tahun 1968 hingga tahun 2010, World Health Organization (WHO) mencatat bahwa Indonesia sebagai negara dengan kasus DBD tertinggi di Asia Tenggara dan kedua di dunia setelah Negara Brazil (WHO, 2012). Jumlah provinsi dan kabupaten/kota yang endemis DBD pun meningkat, dari 2 provinsi dan 2 kota, menjadi 32 (97\%) provinsi dan $382(77 \%)$ kabupaten/kota pada tahun 2009. Selain itu terjadi juga peningkatan jumlah kasus DBD, pada tahun 1968 hanya 58 kasus menjadi 158.912 kasus pada tahun 2009 (Brahim et al., 2010). Upaya pemerintah (Kementerian Kesehatan) dalam pencegahan DBD meliputi peningkatkan Sistem Kewaspadaan Dini (SKD) dan pengendalian vektor. Pengendalian vektor melalui survailans vektor, pembudayaan Pemberantasan Sarang Nyamuk (PSN 3M Plus) yang dilakukan secara berkelanjutan sepanjang tahun oleh masyarakat (Kepmenkes RI, 1992).

Selain itu, pemerintah juga mengupayakan terbentuknya kelompok kerja operasional (Pokjanal) DBD di setiap tingkat administrasi dan melakukan revitalisasi Pokjanal DBD yang sudah ada dengan dukungan APBD, upaya promosi kesehatan di semua sektor termasuk pembentukan juru pemantau jentik (JUMANTIK) pada anak sekolah dan pramuka, penemuan kasus dini dan pengobatan segera, yang merupakan bagian dari tatalaksana kasus di fasilitas pelayanan kesehatan tingkat pertama dan lanjutan. Upaya lainnya yang dilakukan adalahpelaksanaan surveilans kasus DBD untuk memantau dinamika kejadian DBD sehingga kemungkinan terjadinya KLB DBD dapat diantisipasi dan dicegah sejak dini, serta dilakukannya surveilans vektor Aedes sp untuk memantau dinamika vektor.

Berbagai upaya pengendalian telah dilakukan, namun upaya ini belum menunjukan hasil yang efektif dalam menurunkan kasus (Pusdatin Setjen Kemenkes RI, 2015). Menurut Direktur Pengendalian dan Pencegahan Penyakit Tular Vektor dan Zoonotik (P2PTVZ) Kementerian Kesehatan, pada Februari 2019 terdapat 15.132 kasus dengue, dengan 145 kasus kematian di seluruh Indonesia. Provinsi dengan kasus dan kematian akibat DBD paling tinggi saat ini adalah Provinsi Jawa Timur dengan 3.074 kasus dan 52 kematian, Jawa Barat dengan 2.204 kasus dengan 14 kematian, Nusa Tenggara Timur (NTT) dengan 1.092 kasus dan 13 kematian, dan Sumatera Utara dengan 1.071 kasus dan 13 kematian (Jamil, 2019).

Pengendalian yang efektif dan efisien dalam memutus rantai penularan DBD dan pencegahan risiko terjadinya Kejadian Luar Biasa (KLB) DBD adalah peningkatan peran serta masyarakat pemberantasan sarang nyamuk (PSN) 3M Plus (Fathi et al., 2005, Ooi et al., 2006, Prasetyani, 2015, Puskomblik Setjen Kementerian Kesehatan RI, 2015, Pusdatin Setjen Kemenkes RI, 2015, Kemenkes RI, 2016a, Francisco et al., 2018, Azlina et al., 2016, WHO, 2018). PSN merupakan suatu gerakan pemberantasan sarang nyamuk dengan melakukan 3M Plus. 3M Plus terdiri dari 1) menguras/membersihkan tempat yang sering dijadikan tempat penampungan air seperti bak mandi, ember air, tempat penampungan air minum, penampung air lemari es dan lain-lain; 2) menutup rapat tempat-tempat penampungan air seperti drum, kendi, toren air, dan lain sebagainya; 3) memanfaatkan kembali atau mendaur ulang barang bekas yang memiliki potensi untuk jadi tempat perkembangbiakan nyamuk yang menularkan demam berdarah. Kegiatan plus-nya adalah kegiatan pencegahan DBD lainnya, seperti: 1) menaburkan bubuk larvasida (lebih dikenal dengan bubuk abate) pada tempat penampungan air yang sulit dibersihkan; 2) menggunakan obat nyamuk atau anti nyamuk; 3) menggunakan kelambu saat tidur; 4) memelihara ikan pemakan jentik nyamuk; 5) menanam tanaman pengusir nyamuk; 6) mengatur cahaya dan ventilasi dalam rumah; dan 7) menghindari kebiasaan menggantung pakaian di dalam rumah yang bisa menjadi tempat istirahat nyamuk, dan lainlain (Kemenkes RI, 2016b).

1992 Gerakan PSN mulai dicanangkan pada MENKES/SK/VII/1992 dan dan revisinya yaitu Kepmenkes No. 92 /Menkes /SK/II/ 1994 dan diperkuat dengan Surat Edaran No. PM.01.11/ MENKES/591/ 2016 Tentang Pelaksanaan Pemberantasan Sarang Nyamuk 3M Plus dengan Gerakan Satu Rumah Satu Jumantik. 
Surat Edaran ini dimaksudkan untuk menghimbau dan mendorong masyarakat untuk melakukan upaya pencegahan dan pengendalian DBD dan virus Zika melalui Pemberantasan Sarang Nyamuk (PSN) 3M Plus dengan Gerakan 1 (satu) Rumah 1 (satu) Jumantik (G1R1J) (Kemenkes RI, 2016b). Namun, berdasarkan hasil Riset Kesehatan Dasar (Riskesdas) 2018 menunjukan bahwa perilaku PSN 3M di Indonesia masih rendah $(31,2 \%$ rumah tangga yang melakukan PSN). Provinsi dengan tingkat PSN tertinggi adalah Yogyakarta $(43,6 \%)$ dan terendah adalah Provinsi Kepulauan Riau (16,2\%). Banyak faktor yang mempengaruhi praktik PSN DBD oleh masyarakat termasuk faktor sosiodemografi. Beberapa penelitian menunjukan bahwa pengetahuan tentang bahaya DBD berpengaruh terhadap perilaku PSN oleh masyarakat (Supriyanto and Suharto, 2011, Monintja, 2015, Bakta and Bakta, 2015). Demikian pula penelitian Utami (2010) menunjukan bahwa pendidikan formal berpengaruh terhadap perilaku pencegahan DBD. Pekerjaan memiliki pengaruh pada pengetahuan seseorang. Lingkungan pekerjaan dapat menjadikan seseorang memperoleh pengalaman dan pengetahuan baik secara langsung maupun tidak langsung (Notoatmodjo, 2010). Beberapa penelitian mengenai hubungan pekerjaan terhadap perilaku PSN menunjukan hasil yang masih kontradiktif. Penelitian Maulida (2016) menjelaskan bahwa ada hubungan signifikan antara kepala keluarga yang bekerja dengan perilaku PSN. Namun, penelitian Adian (2010), Rezania dan Handayani (2015), dan Bakta dan Bakta (2015) menunjukan hasil yang sebaliknya. Berdasarkan fakta-fakta tersebut diatas dan masih adanya kontradiksi hasil analisis maka perlu gambaran lebih jelas dengan data yang lebih besar untuk melihat pengaruh karakteristik sosiodemografi dan perilaku pencegahan gigitan nyamuk rumah tangga terhadap perilaku PSN.

\section{BAHAN DAN CARA}

Artikel ini menggunakan data Riskesdas 2018 dengan unit analisis Rumah Tangga dan Individu. Riskesdas 2018 merupakan riset skala nasional berbasis komunitas dengan desain potong lintang. Jumlah sampel dihitung untuk menggambarkan masalah kesehatan penduduk di seluruh
Indonesia, keterwakilan sampel penduduk baik di tingkat nasional, provinsi, dan kabupaten/kota. Sampel Riskesdas 2018 menggunakan kerangka sampel suvey sosial ekonomi (Susenas) 2018 sebanyak 300.000 rumah tangga dari 30.000 Blok Sensus (BS). Sampling dilakukan dengan metode probability proportional to size (PPS) menggunakan linear systematic sampling, dengan Two Stage Sampling. Pemilihan BS dilakukan dengan dengan metode PPS disetiap strata urban/ rural per Kabupaten/ Kota dengan systematic random sampling (Badan Penelitian dan Pengembangan Kesehatan Kemkes RI, 2018).

Variabel dependen pada analisis ini adalah perilaku masyarakat yang melakukan PSN, yaitu menguras bak mandi/ ember besar/ drum, menutup tempat penampungan air di rumah tangga, memusnahkan barang-barang bekas (kaleng, ban, dll), memakai obat nyamuk (semprot/ bakar/ elektrik), menaburkan bubuk larvasida dalam tempat penampungan air, ventilasi rumah dipasang kasa nyamuk. Data kemudian dibagi menjadi 2 kategori yaitu 1 "Ya" jika rumah tangga melakukan PSN yaitu menguras bak mandi/ ember besar/ drum, menutup tempat penampungan air di rumah tangga, memusnahkan barang-barang bekas (kaleng, ban, dll) dan melakukan salah satu tindakan pencegahan sebagai berikut memakai obat nyamuk (semprot/ bakar/ elektrik); menaburkan bubuk larvasida dalam tempat penampungan air; ventilasi rumah dipasang kasa nyamuk. 2 "Tidak" jika tidak melakukan PSN. Data ini diperoleh dari data rumah tangga Riskesdas 2018 tentang pencegahan penularan penyakit akibat gigitan nyamuk. Pertanyaan ini ditanyakan kepada seluruh rumah tangga terpilih.

Variabel independen adalah karakteristik individu, seperti kelompok umur, pekerjaan dan pendidikan kepala rumah tangga (KRT) dan ibu rumah tangga (IRT), karakteristik wilayah (Perkotaan dan Perdesaan), menggunakan repelen/ bahan-bahan pencegah gigitan nyamuk, penggunaan। kelambu, dan menggunakan alat pembasmi nyamuk elektrik (contoh: raket nyamuk elektrik). Analisis dilakukan untuk memperoleh faktor prediktor yang berpengaruh terhadap perilaku KRT, IRT dalam melakukan PSN. Hal ini dilakukan untuk memperoleh gambaran pola pendekatan terbaik dalam meningkatan perilaku PSN pada kelompok kepala rumah tangga dan 
Ibu rumah tangga. Pada penelitian ini definisi KRT dan IRT sesuai dengan data Riskesdas 2018, KRT adalah jika pada variabel hubungan dengan Kepala Keluarga (KK) adalah berkode 1"Kepala Keluarga", sedangkan yang dimaksud dengan IRT adalah jika hubungan dengan KK berkode 2 "Istri/Suami" dan pada variabel jenis kelamin berkode 2 "Perempuan". Data ini diperoleh juga dari data rumah tangga Riskesdas 2018 tentang keterangan anggota rumah tangga. Analisis data dilakukan mengggunakan uji chi-square and uji multiple logistic regression.

\section{HASIL}

Proporsi rumah tangga yang melakukan PSN menurut kabupaten/kota di Indonesia di tampilkan pada Gambar 1. Perilaku rumah tangga dalam melakukan PSN di sebagian besar kabupaten/kota masih lebih rendah dibandingkan dengan rerata nasional $(31,20 \%)$. Di Pulau Jawa dan Bali terutama di Provinsi Jawa Tengah, Jawa Timur, DKI Jakarta dan Bali merupakan provinsi yang lebih dari separuh kabupaten/kotanya dengan tingkat proporsi PSN paling banyak dilakukan dibanding provinsi lainnya. Sedangkan diluar Pulau Jawa, wilayah di Sulawesi Tengah dan Tenggara nampaknya perilaku PSN-nya lebih baik dibandingkan dengan daerah lainnya.

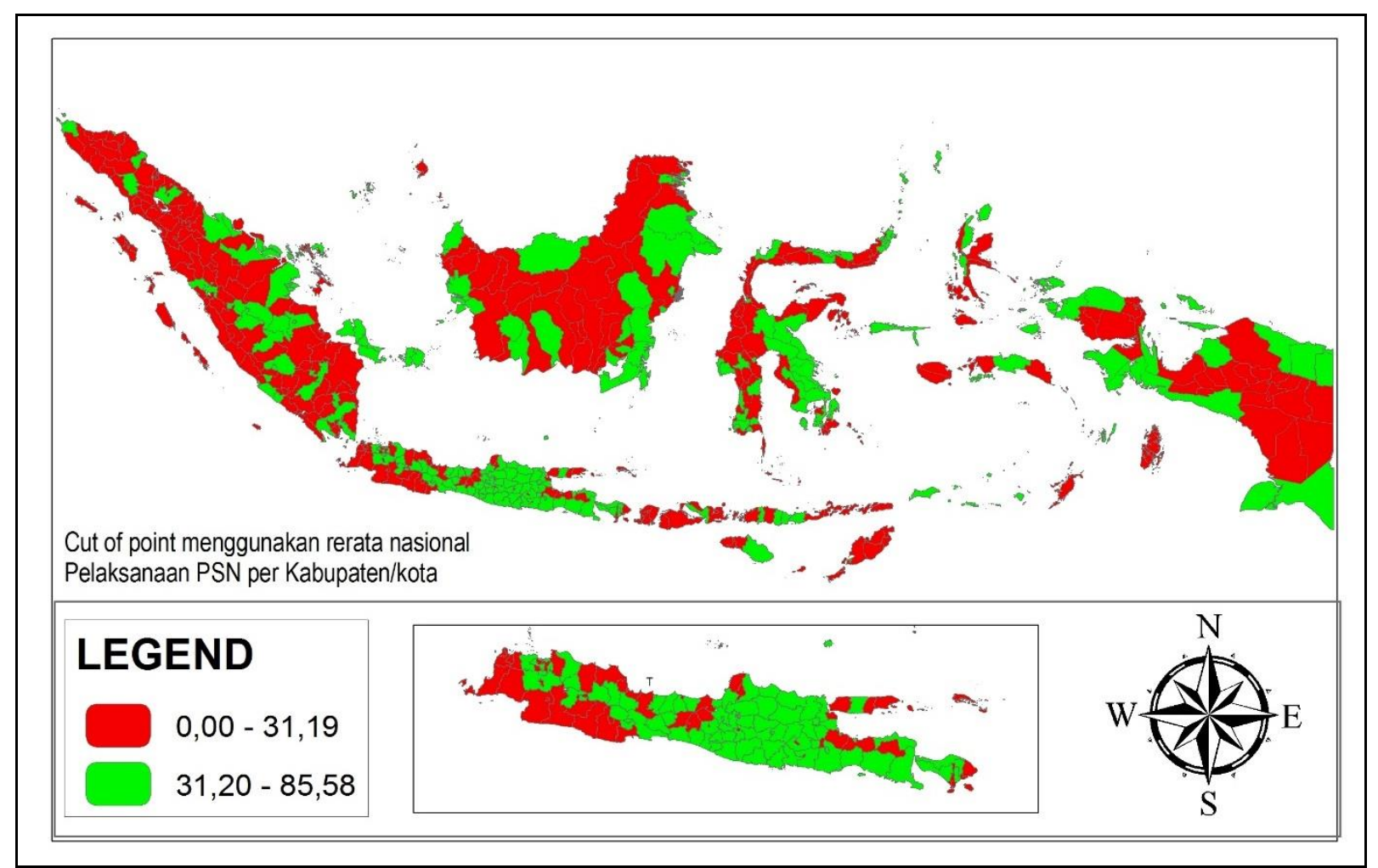

Gambar 1. Proporsi rumah tangga yang melakukan PSN menurut kabupaten/ kota (Riskesdas 2018).

Tabel 1 memperlihatkan perilaku PSN berdasarkan karakteristik KRT dan IRT, yang menunjukan bahwa proporsi tertinggi pada kelompok umur 41-70 Tahun (32,2-33,15\%), uji bivariate menunjukan signifikansi dengan Crude OR pada kelompok tersebut 1,6-1,67 dibandingkan dengan referensi (kelompok KRT dibawah 20 Tahun). Jika dilihat berdasarkan pendidikan KRT terakhir menunjukan pola linier yaitu semakin tinggi pendidikan semakin tinggi proporsi PSN. Hal ini diperkuat dengan uji bivariat yang menunjukan signifikansi dengan Crude OR yang semakin meningkat sesuai tingkat pendidikan dengan referensi (Tidak sekolah). Pekerjaan memberikan gambaran berbeda terhadap proporsi KRT dalam melakukan PSN, KRT dengan pekerjaan ASN, pegawai swasta, dan wiraswasta menunjukan proporsi tertinggi dengan perbedaan yang signifikan. Jika dibandingkan dengan referensi (tidak bekerja) petani dan nelayan menunjukan perbedaan bermakna namun bersifat protektif. Jika dilihat dari wilayah, proporsi Kepala RT yang mengaku 
melaksanakan PSN tidak menunjukan perdesaan (Tabel 1) perbedaan bermakna antara perkotaan dan

Tabel 1. Proporsi rumah tangga yang melakukan PSN (3M) menurut karakteristik individu KRT dan IRT

\begin{tabular}{|c|c|c|c|c|c|c|c|c|}
\hline \multirow{3}{*}{ Karakteristik Individu } & \multicolumn{8}{|c|}{ Melaksanakan PSN } \\
\hline & \multicolumn{4}{|c|}{ Karakteristik KRT } & \multicolumn{4}{|c|}{$\begin{array}{ll}\text { Karakteristik IRT } \\
\end{array}$} \\
\hline & Ya & OR & $95 \% \mathrm{CI}$ & $\mathbf{N}$ & Ya & Crude OR & $95 \% \mathrm{CI}$ & $\mathbf{N}$ \\
\hline \multicolumn{9}{|l|}{ Kelompok Umur } \\
\hline$<20$ Tahun & 22,9 & & Referensi & 1478 & 22.33 & Referensi & & 1754 \\
\hline 21-30 Tahun & 26,46 & 1,21 & $1,01-1,45$ & 18274 & 28.57 & 1,31 & $1,10-1,56$ & 30977 \\
\hline 31-40 Tahun & 30,45 & 1,47 & $1,23-1,76$ & 56949 & 31.82 & 1,56 & $1,31-1,85$ & 65733 \\
\hline 41-50 Tahun & 32,34 & 1,61 & $1,35-1,92$ & 71638 & 33.57 & 1,77 & $1,49-2,11$ & 61532 \\
\hline 51-60 Tahun & 33,15 & 1,67 & $1,40-1,99$ & 60965 & 33.56 & 1,9 & $1,59-2,27$ & 38090 \\
\hline 61-70 Tahun & 32,22 & 1,6 & $1,34-1,91$ & 35723 & 33.08 & 1,98 & $1,65-2,36$ & 13190 \\
\hline $70+$ Tahun & 29,92 & 1,44 & $1,20-1,72$ & 17890 & 32.04 & 1,95 & $1,59-2,40$ & 3072 \\
\hline \multicolumn{9}{|l|}{ Pendidikan Terakhir/ } \\
\hline \multicolumn{9}{|l|}{ Tertinggi } \\
\hline PT & 39,26 & 1,79 & $1,65-1,95$ & 15699 & 39.23 & 1,73 & $1,56-1,92$ & 12360 \\
\hline D1/D2/D3 & 38,22 & 1,77 & $1,60-1,96$ & 6730 & 39.34 & 1,80 & $1,61-2,00$ & 6975 \\
\hline SLTA & 3,71 & 1,54 & $1,45-1,65$ & 62882 & 34.33 & 1,54 & $1,43-1,66$ & 47578 \\
\hline SLTP/MTS & 31,44 & 1,43 & $1,34-1,52$ & 41944 & 32.93 & 1,49 & $1,38-1,60$ & 39652 \\
\hline Tamat SD/MI & 29,95 & 1,30 & $1,23-1,38$ & 72773 & 30.06 & 1,24 & $1,16-1,33$ & 63783 \\
\hline Tidak Tamat SD/MI & 28,11 & 1,17 & $1,10-1,24$ & 42660 & 28.49 & 1,12 & $1,05-1,21$ & 30728 \\
\hline $\begin{array}{l}\text { Tidak/Belum } \\
\text { Pernah Sekolah }\end{array}$ & 25,32 & & Referensi & 20229 & 26.41 & Referensi & & 13272 \\
\hline \multicolumn{9}{|l|}{ Status Pekerjaan } \\
\hline Tidak bekerja & 31,01 & & Referensi & 29614 & 31.66 & Referensi & & 99953 \\
\hline Sekolah & 27,06 & 1,03 & $0,85-1,25$ & 1767 & 27.22 & 0,8 & $0,65-0,99$ & 895 \\
\hline $\begin{array}{l}\text { PNS/ TNI/ Polri } \\
\text { / BUMN/ BUMD }\end{array}$ & 40,15 & 1,23 & $1,14-1,32$ & 15238 & 42.23 & 1,18 & $1,09-1,28$ & 9447 \\
\hline Pegawai swasta & 33,97 & 1,13 & $1,05-1,20$ & 20988 & 35.46 & 1,08 & $1,00-1,16$ & 8056 \\
\hline Wiraswasta & 3,93 & 1,14 & $1,09-1,20$ & 49181 & 35.8 & 1,15 & $1,10-1,20$ & 23631 \\
\hline Petani & 27,78 & 0,92 & $0,87-0,96$ & 95599 & 27.43 & 0,86 & $0,83-0,90$ & 46736 \\
\hline Nelayan & 26,53 & 0,89 & $0,79-1,00$ & 6363 & 25.54 & 0,75 & $0,52-1,09$ & 412 \\
\hline $\begin{array}{l}\text { Buruh/ sopir/ } \\
\text { pembantu ruta }\end{array}$ & 30,36 & 1,03 & $0,98-1,09$ & 30030 & 32.23 & 1,05 & $0,98-1,13$ & 7614 \\
\hline Lainnya & 32,09 & 1,02 & $0,95-1,09$ & 14137 & 31.59 & 0,97 & $0,92-1,03$ & 17604 \\
\hline \multicolumn{9}{|l|}{ Wilayah } \\
\hline Perkotaan & 32,8 & 1 & $0,96-1,04$ & 111108 & 33.68 & 1,02 & $0,98-1,07$ & 88461 \\
\hline Perdesaan & 29,51 & & & 151809 & 30.02 & Referensi & & 125887 \\
\hline INDONESIA & 31,31 & & & 262917 & 31.98 & & & 214348 \\
\hline
\end{tabular}

Perilaku PSN berdasarkan karakteristik IRT menunjukan bahwa proporsi tertinggi pada kelompok umur 41-70 + (32,04-33,57\%), uji bivariate menunjukan signifikansi dengan Crude OR pada kelompok tersebut 1,77-1,98 dibandingkan dengan referensi (kelompok IRT dibawah 20 Tahun). Jika dilihat berdasarkan pendidikan IRT terakhir, menunjukan pola linier yaitu semakin tinggi pendidikan semakin tinggi proporsi melakukan PSN. Hal ini diperkuat dengan uji bivariat yang menunjukan signifikansi dengan Crude OR yang semakin meningkat sesuai tingkat pendidikan dengan referensi (tidak sekolah). Jenis pekerjaan memberikan gambaran yang berbeda terhadap proporsi IRT dalam melakukan PSN, IRT dengan pekerjaan ASN, pegawai swasta, dan wiraswasta menunjukan proporsi tertinggi dengan perbedaan yang signifikan. Jika dilihat dari wilayah, proporsi IRT yang mengaku melaksanakan PSN tidak menunjukan perbedaan bermakna antara perkotaan dan perdesaan (Tabel 1)

Hasil analisis terhadap perilaku rumah tangga yang melakukan pencegahan gigitan nyamuk ditampilkan pada Tabel 2. Proporsi kepala rumah tangga yang melakukan pencegahan gigitan nyamuk dengan cara menggunakan obat anti nyamuk (semprot 
/bakar/ elektrik, menaburkan bubuk larvasida pada tempat penampungan air, ventilasi rumah dipasang kasa nyamuk, menggunakan repelen/ bahan-bahan pencegah gigitan nyamuk, menggunakan raket nyamuk elektrik) menunjukan perbedaan signifikan dengan
Crude OR positif (dengan referensi tidak). Pengggunaan kelambu baik berinsektisida maupun tidak, menunjukan perbedaan bermakna dengan crude OR bersifat protektif (Tabel 2).

Tabel 2. Proporsi perilaku rumah tangga yang pencegahan gigitan nyamuk KRT dan IRT

\begin{tabular}{|c|c|c|c|c|c|c|c|c|}
\hline \multirow{3}{*}{$\begin{array}{l}\text { Jenis cara } \\
\text { pencegahan gigitan } \\
\text { nyamuk }\end{array}$} & \multicolumn{8}{|c|}{ Melaksanakan PSN } \\
\hline & \multicolumn{4}{|c|}{ KRT } & \multicolumn{4}{|c|}{ IRT } \\
\hline & Ya & $\begin{array}{l}\text { Crude } \\
\text { OR }\end{array}$ & $95 \% \mathrm{CI}$ & $\mathbf{N}$ & Ya & Crude OR & $95 \% \mathrm{CI}$ & $\mathbf{N}$ \\
\hline \multicolumn{9}{|c|}{ Memakai obat nyamuk (semprot /bakar/ elektrik } \\
\hline Ya & 32,81 & 1,2 & $1,17-1,24$ & 159678 & 33,22 & 1,17 & $1,13-1,2$ & 133261 \\
\hline Tidak & 28,91 & Referensi & & 103239 & 29,91 & & & 81087 \\
\hline \multicolumn{9}{|c|}{ Menaburkan bubuk larvasida pada tempat penampungan air } \\
\hline Ya & 47,75 & 2,23 & $2,14-2,32$ & 30588 & 47,77 & 2,16 & $2,07-2,26$ & 26026 \\
\hline Tidak & 29,05 & Referensi & & 232329 & 29,71 & & & 188322 \\
\hline \multicolumn{9}{|c|}{ Ventilasi rumah dipasang kasa nyamuk } \\
\hline Ya & 41,8 & 1,75 & $1,68-1,83$ & 36580 & 42,36 & 1,74 & $1,67-1,82$ & 30736 \\
\hline Tidak & 29,06 & Referensi & & 226337 & 29,69 & & & 183612 \\
\hline \multicolumn{9}{|c|}{ Tidur menggunakan kelambu tanpa nsektisida } \\
\hline Ya & 29,81 & 0,92 & $0,89-0,95$ & 71236 & 30,59 & 0,92 & $0,89-0,96$ & 60849 \\
\hline Tidak & 31,67 & Referensi & & 191681 & 32,36 & & & 153499 \\
\hline \multicolumn{9}{|c|}{ Tidur menggunakan kelambu dengan berinsektisida $<3$ tahun } \\
\hline Ya & 25,88 & 0,76 & $0,72-0,81$ & 18896 & 29,79 & 0,77 & $0,72-0,82$ & 10800 \\
\hline Tidak & 31,48 & Referensi & & 244021 & 32,04 & & & 203548 \\
\hline \multicolumn{9}{|c|}{ Tidur menggunakan kelambu dengan berinsektisida $>\mathbf{3}$ tahun } \\
\hline Ya & 28,78 & 0,88 & $0,83-0,94$ & 12217 & 26,73 & 0,9 & $0,84-0,96$ & 16437 \\
\hline Tidak & 31,37 & Referensi & & 250700 & 32,17 & & & 197911 \\
\hline \multicolumn{9}{|c|}{ Menggunakan repelen/ bahan-bahan pencegah gigitan nyamuk } \\
\hline Ya & 32,31 & 1,1 & $1,06-1,13$ & 117339 & 32,64 & 1,06 & $1,03-1,1$ & 98964 \\
\hline Tidak & 30,35 & Referensi & & 145578 & 31,32 & & & 115384 \\
\hline \multicolumn{9}{|c|}{ Menggunakan raket nyamuk elektrik } \\
\hline $\mathrm{Ya}$ & 37,13 & 1,34 & $1,28-1,40$ & 24793 & 37,57 & 1,32 & $1,26-1,38$ & 21152 \\
\hline Tidak & 30,64 & Referensi & & 238124 & 31,3 & & & 193196 \\
\hline
\end{tabular}

Proporsi IRT yang melakukan pencegahan gigitan nyamuk dengan cara memakai obat anti nyamuk (semprot /bakar/ elektrik, menaburkan bubuk larvasida pada tempat penampungan air, ventilasi rumah dipasang kasa nyamuk, menggunakan repelen/ bahan-bahan pencegah gigitan nyamuk, menggunakan raket nyamuk elektrik) menunjukan perbedaan yang signifikan dengan Crude OR positif. Pengggunaan kelambu baik berinsektisida maupun tidak menunjukan perbedaan bermakna dengan Crude OR bersifat negatif (Tabel 2).

Tabel 3. Menampilkan hasil uji regresi logistik antara karakteristik individu, cara pencegahan individu dan keluarga, terhadap gigitan nyamuk. Analisis multivariat ini menggunakan uji regresi logistik berganda. uji yang dilakukan dalam beberapa tahap: 1) melakukan uji colinierity, jika terjadi colinierity maka variabel dikeluarkan; 2) melakukan uji regresi logistik pada semua variabel kemudian 3) mengeluarkan variabel dengan alpha $>0,25$ secara bertahap dimulai dengan variabel dengan nilai alpha paling besar.

Hasil analisis menunjukan bahwa variabel yang masuk dalam uji multivariat adalah kelompok umur, tingkat pendididikan, jenis pekerjaan, upaya pencegahan gigitan nyamuk melalui memakai obat nyamuk (semprot /bakar/ elektrik, ventilasi rumah dipasang kasa nyamuk, tidur menggunakan kelambu tanpa insektisida, menggunakan repelen/ bahan-bahan pencegah gigitan, dan menggunakan raket nyamuk elektrik nyamuk secara signifikan berpengaruh terhadap perilaku pemberantasan sarang nyamuk (PSN) pada kepala rumah tangga ( KRT). Pengaruh terbesar adalah larvasidasi penampungan air, sedangkan penggunaan kelambu baik kelambu berinsektisida maupun tidak hubungan bersifat protektif $(\mathrm{OR}<1)$. 
Tabel 3. Regresi logistik karakteristik individu, cara pencegahan individu dan keluarga terhadap gigitan nyamuk terhadap PSN

\begin{tabular}{|c|c|c|c|c|c|c|}
\hline \multirow{3}{*}{ Karakteristik } & \multicolumn{6}{|c|}{ Melakukan PSN } \\
\hline & \multicolumn{3}{|c|}{ KRT } & \multicolumn{3}{|c|}{ IRT } \\
\hline & $\begin{array}{l}\text { Adjust } \\
\text { ed OR }\end{array}$ & Nilai $\mathbf{P}$ & $95 \% \mathrm{CI}$ & $\begin{array}{l}\text { Adjust } \\
\text { ed OR }\end{array}$ & Nilai P & $95 \% \mathrm{CI}$ \\
\hline \multicolumn{7}{|l|}{ Kelompok Umur } \\
\hline$<20$ Tahun & Referensi & & & & & \\
\hline 21-30 Tahun & 1,19 & 0,02 & $1,03-1,36$ & 1,31 & 0,00 & $1,17-1,48$ \\
\hline 31-40 Tahun & 1,38 & 0,00 & $1,2-1,59$ & 1,51 & 0,00 & $1,34-1,7$ \\
\hline 41-50 Tahun & 1,52 & 0,00 & $1,33-1,75$ & 1,64 & 0,00 & $1,46-1,85$ \\
\hline 51-60 Tahun & 1,66 & 0,00 & $1,45-1,91$ & 1,83 & 0,00 & $1,63-2,07$ \\
\hline 61-70 Tahun & 1,76 & 0,00 & $1,53-2,02$ & 1,97 & 0,00 & $1,74-2,23$ \\
\hline 70+ Tahun & 1,72 & 0,00 & $1,5-1,98$ & 1,95 & 0,00 & $1,69-2,24$ \\
\hline Tingkat Pendidikan & & & - & & & - \\
\hline Tidak Sekolah & Referensi & & & & & \\
\hline Tidak tamat SD/MI & 1,22 & 0,00 & $1,17-1,27$ & 1,20 & 0,00 & $1,14-1,26$ \\
\hline Tamat SD/MI & 1,36 & 0,00 & $1,31-1,41$ & 1,33 & 0,00 & $1,27-1,39$ \\
\hline Tamat SLTP/MTS & 1,44 & 0,00 & $1,38-1,5$ & 1,49 & 0,00 & $1,42-1,56$ \\
\hline Tamat SLTA/MA & 1,53 & 0,00 & $1,47-1,59$ & 1,53 & 0,00 & $1,46-1,6$ \\
\hline Tamat D1/D2/D3 & 1,67 & 0,00 & $1,56-1,78$ & 1,61 & 0,00 & $1,5-1,73$ \\
\hline Tamat PT & 1,75 & 0,00 & $1,65-1,84$ & 1,62 & 0,00 & $1,52-1,73$ \\
\hline Pekerjaan & & & - & & & - \\
\hline Tidak Bekerja & Referensi & & & & & \\
\hline Sekolah & 1,02 & 0,72 & $0,91-1,15$ & 0,88 & 0,08 & $0,76-1,02$ \\
\hline PNS/ TNI/ Polri/ BUMN/ BUMD & 1,21 & 0,00 & $1,16-1,27$ & 1,21 & 0,00 & $1,15-1,28$ \\
\hline Pegawai swasta & 1,07 & 0,00 & $1,03-1,12$ & 1,07 & 0,01 & $1,02-1,13$ \\
\hline Wiraswasta & 1,14 & 0,00 & $1,1-1,18$ & 1,12 & 0,00 & $1,08-1,15$ \\
\hline Petani & 0,93 & 0,00 & $0,9-0,96$ & 0,80 & 0,00 & $0,78-0,82$ \\
\hline Nelayan & 0,96 & 0,23 & $0,9-1,02$ & 0,77 & 0,03 & $0,62-0,97$ \\
\hline Buruh/ sopir/ pembantu ruta & 1,12 & 0,00 & $1,08-1,17$ & 1,08 & 0,00 & $1,03-1,14$ \\
\hline Lainnya & 1,06 & 0,01 & $1,01-1,11$ & 1,02 & 0,32 & $0,98-1,05$ \\
\hline \multicolumn{7}{|l|}{ Cara Perlindungan terhadap Nyamuk } \\
\hline $\begin{array}{l}\text { Memakai obat nyamuk } \\
\text { (semprot /bakar/ elektrik }\end{array}$ & $1,14 *$ & 0,00 & $1,12-1,16$ & 1,11 & 0,00 & $1,09-1,14$ \\
\hline $\begin{array}{l}\text { Menaburkan bubuk larvasida } \\
\text { pada tempat penampungan air }\end{array}$ & $2,07 *$ & 0,00 & $2,02-2,12$ & 2,02 & 0,00 & $1,96-2,07$ \\
\hline $\begin{array}{l}\text { Ventilasi rumah dipasang } \\
\text { kasa nyamuk }\end{array}$ & $1,61 *$ & 0,00 & $1,57-1,65$ & 1,61 & 0,00 & $1,57-1,66$ \\
\hline $\begin{array}{l}\text { Tidur menggunakan kelambu } \\
\text { tanpa insektisida }\end{array}$ & $0,99 *$ & 0,18 & $0,97-1,01$ & $=$ & $=$ & - \\
\hline $\begin{array}{l}\text { Tidur menggunakan kelambu } \\
\text { dengan berinsektisida }<3 \text { tahun }\end{array}$ & $0,90 *$ & 0,00 & $0,87-0,93$ & 0,92 & 0,00 & $0,88-0,95$ \\
\hline $\begin{array}{l}\text { Menggunakan repelen/ bahan-bahan } \\
\text { pencegah gigitan nyamuk }\end{array}$ & $1,05 *$ & 0,00 & $1,03-1,07$ & 1,03 & 0,01 & $1,01-1,05$ \\
\hline Menggunakan raket nyamuk elektrik & $1,17 *$ & 0,00 & $1,14-1,2$ & 1,14 & 0,00 & $1,11-1,18$ \\
\hline Konstanta & 0,04 & 0,00 & $0,03-0,04$ & 0,04 & 0,00 & $0,04-0,05$ \\
\hline $\mathrm{AIC} * *$ & & $312972 ., 8$ & & & 257703. & \\
\hline $\mathbf{N}$ & & 262917 & & & 214348 & \\
\hline
\end{tabular}

Hasil analisis pada kelompok Ibu Rumah Tangga (IRT), menunjukan bahwa variabel yang masuk dalam uji multivariat adalah kelompok umur, tingkat pendididikan, jenis pekerjaan. Upaya pencegahan gigitan nyamuk melalui penggunaan obat nyamuk (semprot /bakar/ elektrik, ventilasi rumah dipasang kasa nyamuk, tidur menggunakan kelambu berinsektisida $<3$ Tahun, menggunakan repelen/ bahan-bahan pencegah gigitan, dan menggunakan raket nyamuk elektrik nyamuk. Pengaruh terbesar adalah larvasidasi 
penampungan air, sedangkan penggunaan kelambu baik kelambu berinsektisida maupun tidak hubungan bersifat protektif. Sedangkan penggunaan kelambu biasa dan kelambu berinsektisida > 3 tahun di eksklusi pada saat analsis. Berdasarkan AIC, model sosiodemografi dan pencegahan gigitan nyamuk terhadap perilaku PSN lebih fit pada kelompok IRT (Tabel 3).

\section{PEMBAHASAN}

Strategi pencegahan demam berdarah di masyarakat berawal dari komitmen masingmasing anggota masyarakat untuk selalu menjaga kebersihan lingkungan dengan meniadakan tempat-tempat yang berpotensi sebagai perkembangbiakan larva. Tanggung jawab tersebut terlihat dari sikap seseorang terhadap pencegahan demam berdarah (Suwanbamrung, 2012) Kunci sukses dalam menurunkan prevalensi penyakit dengue adalah pengendalian vektor melalui PSN. Hal penting dalam kesuksesan PSN adalah kerjasama dan partisipasi atau keterlibatan masyarakat dengan sektor publik (pemerintah) dan swasta. Peran masyarakat dan berbagai sektor sangat diperlukan untuk memastikan bahwa kegiatan PSN dapat dilakukan lebih sering (setiap minggu) (Mudin, 2015)

Hasil analisis berdasarkan kelompok umur menunjukan bahwa proporsi PSN tinggi pada 41-70 Tahun pada kelompok KRT (32,233,15) dengan Crude OR pada kelompok tersebut 1,6-1,67 dan IRT $(32,04-33,57)$ dengan Crude OR pada kelompok tersebut 1,77-1,98, sedangkan pada kelompok usia sekolah, kelompok umur tidak menunjukan hubungan yang signifikan dibandingkan dengan referensi (kelompok anak sekolah dibawah 5-12 Tahun). Kebanyakan orang menaruh harapan besar pada kelompok penduduk dengan umur yang lebih tua. Perubahan perilaku disebabkan oleh pendewasaan, yaitu semakin dewasa seseorang maka ia akan cepat beradaptasi dengan lingkungannya. Lingkungan dapat berarti lingkungan tempat tinggal dimana seseorang dapat beradaptasi dengan inovasi, dapat mempertimbangkan keuntungan dan kerugian suatu inovasi. Dikatakan oleh Budioro (1998) bahwa semakin dewasa seseorang maka perilaku yang diharapkan akan dapat terjadi (Budioro, 1998)
Pada artikel ini tingkat pendidikan merupakan proksi terhadap pengetahuan rumah tangga tentang perilaku pencegahan penyakit DBD dan pentingnya PSN. Temuan ini memperkuat hasil penelitian sebelumnya yang menyatakan bahwa pengetahuan merupakan satu faktor yang sangat berpengaruh terhadap perilaku PSN oleh masyarakat (Monintja, 2015, Supriyanto and Suharto, 2011, Bakta and Bakta, 2015).

Berapa hal dapat yang menjelaskan pendidikan secara konsisten sangat berpengaruh terhadap semua perilaku kesehatan, diantaranya dengan pendidikan dapat mempermudah mendapat pengetahuan tentang manfaat perawatan kesehatan preventif dan penggunaan pelayanan kesehatan, lebih mudah untuk menerima informasi kesehatan baru, lebih mudah tersosialisasi dengan layanan formal di luar lingkungan rumah, lebih mudah menerima budaya medis modern, hubungan yang lebih egaliter dan komunikasi yang lebih baik dalam keluarga, lebih mandiri dalam mengambil keputusan (bagi Ibu), meningkatkan kepercayaan diri, memiliki coping skill dan negosiasi yang lebih baik, sehingga mampu mengurangi perbedaan kekuasaan antara rumah tangga dan penyedia jasa layanan. (Thaddeus and Maine, 1994, Bell et al., 2003, Gabrysch and Campbell, 2009). Temuan analisis menunjukan bahwa tingkat pendidikan merupakan variabel yang secara signifikan mempengaruhi perilaku PSN di Indonesia, semakin tinggi pendidikan semakin baik perilaku PSN.

Status pekerjaan dapat menjadi predisposing factor untuk menghambat ataupun mendorong tindakan seseorang untuk berperilaku hidup sehat (Green and Kreuter, 1991). Hal ini disebabkan faktor pekerjaan menyebabkan masyarakat relatif tidak memiliki waktu untuk melaksanakan PSN. Temuan penelitian ini berbeda dengan teori ini dimana sebaliknya ASN (PNS/TNI/ Polri/ Pegawai BUMN/D), wiraswasta dan pegawai swasta merupakan jenis pekerjaan dengan proporsi perilaku PSN lebih baik diantara jenis pekerjaan lainnya. Hasil analisis juga kontradiktif dengan hasil penelitian sebelumnya yang menyebutkan bahwa perilaku penegahan DBD lebih banyak dilakukan oleh responden yang tidak bekerja atau pekerja tidak membutuhkan skill (unskilled worker) (Wong et al., 2015, Hasyim, 2016). Salah satu alasannya adalah kemungkinan 
aksesibilitas orang yang bekerja terhadap pengetahuan mengenai DBD dan cara pencegahan lebih baik dibandingkan dengan unskilled workers (petani, buruh tani dan orang yang tidak bekerja).

Beberapa cara yang bisa dilakukan untuk menghindari gigitan nyamuk Aedes, yaitu tidur dengan kelambu, menggunakan obat oles anti nyamuk (repelen), memasang kawat nyamuk (berukuran 18 mesh) pada jendela dan lubang-lubang ventilasi lainnya, memakai pakaian yang cukup tebal atau longgar, menggunakan obat anti nyamuk, tidur siang menggunakan pelindung, menyingkirkan pakaian-pakaian di balik pintu di dalam kamar, dan membersihkan serta melancarkan aliran air (got) yang tersumbat (Nadesul, 1998, Yatim, 2001). Pada artikel ini ditemukan bahwa kebiasaan penggunaan obat nyamuk (semprot /bakar/ elektrik, menaburkan bubuk larvasida pada tempat penampungan air, ventilasi rumah dipasang kasa nyamuk, menggunakan repelen/ bahan-bahan pencegah gigitan nyamuk serta menggunakan raket nyamuk elektrik menunjukan perbedaan perilaku PSN yang signifikan, dengan crude $O R$ positif baik pada KRT maupun IRT. Sebaliknya pengggunaan kelambu baik berinsektisida maupun tidak, menunjukan perbedaan perilaku PSN bermakna dengan crude OR bersifat protektif. Tingginya perilaku PSN terutama pada keluarga yang melakukan larvasidasi diasumsikan karena terpapar dengan penyuluhan kesehatan dari petugas kesehatan sehingga memiliki pengetahuan lebih baik (Koenraadt et al., 2006).

Faktor lainnya adalah ventilasi rumah dan pencahayaan, ventilasi memiliki berbagai fungsi yaitu membebaskan udara ruangan dari bau-bauan, asap ataupun debu dan zat-zat pencemar lain dengan cara pengenceran udara. Ventilasi alamiah merupakan aliran udara di dalam ruangan tersebut terjadi secara alamiah melalui jendela, pintu, lubang angin, lubanglubang pada dinding. Ventilasi alamiah ini biasanya merupakan jalan masuk untuk serangga ataupun nyamuk (Notoatmodjo, 2003). Sebuah penelitian menunjukan bahwa pencahayaan berpengaruh terhadap produksi telur nyamuk Aedes aegypti, nyamuk Aedes aegypti yang hidup di pencahayaan lingkungan gelap menghasilkan telur lebih banyak dibandingkan yang dipelihara di pencahayaan lingkungan terang sehingga dapat disimpulkan pencahayaan berhubungan secara bermakna terhadap jumlah produksi telur (Untoro, 1992).

Selain itu cahaya juga merupakan faktor utama yang mempengaruhi nyamuk beristirahat pada suatu tempat intensitas cahaya yang rendah dan kelembaban yang tinggi merupakan kondisi yang baik bagi nyamuk intensitas cahaya merupakan faktor terbesar yang mempengaruhi aktivitas terbang nyamuk, nyamuk terbang apabila intensitas cahaya rendah (Untoro, 1992, Waluyo and Nurullita, 2011). Larva dari nyamuk Aedes aegypti dapat bertahan lebih baik di ruangan dalam kontainer yang gelap dan juga menarik nyamuk betina untuk meletakkan telurnya. Dalam bejana yang intensitas cahaya rendah atau gelap rata-rata berisi larva lebih banyak dari bejana yang intensitas cahanya besar atau terang (Untoro, 1992).

\section{KESIMPULAN DAN SARAN}

\section{Kesimpulan}

Karakteristik sosiodemograpi yang mempengaruhi perilaku PSN diantaranya usia KRT dan IRT yaitu, kelompok usia yaitu paling baik pada usia antara $40-70$ tahun. Pengetahuan (dengan proksi tingkat pendidikan) masih konsisten berpengaruh terhadap perilaku PSN dengan pola linier makin tinggi pendidikan makin tinggi proporsi yang melakukan PSN. Jenis Pekerjaan ASN (PNS/TNI/Polri/Pegawai BUMN/D) merupakan jenis pekerjaan dengan proporsi perilaku PSN paling tinggi diantara jenis pekerjaan. Dari sisi wilayah, kesadaran penduduk perkotaan dalam melakukan PSN lebih baik dibanding perdesaan. Penduduk yang menggunakan kelambu baik berinsektida maupun tidak berinsektisida memiliki kesadaran lebih rendah untuk melakukan PSN dibanding yang tidak menggunakan kelambu.

Pada analisis multivariat kelompok ibu dan kepala rumah tangga menunjukan bahwa variabel yang masuk dalam analisis adalah kelompok umur, tingkat pendididikan, jenis pekerjaan. Upaya pencegahan gigitan nyamuk menggunakan obat anti nyamuk (semprot /bakar/ elektrik), ventilasi rumah dipasang kasa nyamuk, tidur menggunakan kelambu berinsektisida $<3$ Tahun, menggunakan repelen/ bahan-bahan pencegah gigitan, dan menggunakan raket nyamuk elektrik nyamuk. Pengaruh terbesar adalah larvasidasi 
penampungan air, sedangkan penggunaan kelambu baik kelambu berinsektisida maupun tidak hubungan bersifat protektif.

\section{Saran}

Perlu peningkatan kanal/media komunikasi edukasi dengan masyarakat terutama pada masyarakat dengan KRT dan IRT (< 40), Anak sekolah SMP, SMA, dan mahasiswa tentang PSN.

Perlu edukasi pada penggunaan kelambu untuk pencegahan gigitan nyamuk, sehingga pemberantasan sarang nyamuk tetap dilakukan dan tidak ditinggalkan.

\section{UCAPAN TERIMAKASIH}

Penulis mengucapkan terimakasih kepada Kepala Puslitbang Upaya Kesehatan Masyarakat yang telah mengijinkan penulis melakukan analisis data Riset Kesehatan Dasar Tahun 2018, Dra. Rr. Rachmalina S., MScPH dan Bapak Drs. Max Joseph Herman Apt., M.Kes yang telah memberikan bimbingan dalam penulisan artikel ini

\section{DAFTAR PUSTAKA}

Adian, U. K. (2010) Hubungan Tingkat Pendidikan Formal Terhadap Perilaku Pencegahan Demam Berdarah Dengue (DBD) Pada Masyarakat di Kelurahan Bekonang, Sukoharjo. Universitas Sebelas Maret.

Azlina, A., Adrial, A. \& Anas, E. (2016) Hubungan Tindakan Pemberantasan Sarang Nyamuk dengan Keberadaan Larva Vektor DBD di Kelurahan Lubuk Buaya. Jurnal Kesehatan Andalas, 5(1).

Badan Penelitian dan Pengembangan Kesehatan Kemkes RI (2018) Laporan Nasional Riskesdas 2018. Jakarta: Lembaga Penerbit Badan Penelitian dan Pengembangan Kesehatan.

Bakta, N. N. Y. K. \& Bakta, I. M. (2015) Hubungan Antara Pengetahuan Dan Sikap Terhadap Perilaku Pemberantasan Sarang Nyamuk (Psn) Sebagai Pencegahan Demam Berdarah Dengue (DBD) Di Banjar Badung, Desa Melinggih, Wilayah Puskesmas Payangan Tahun 2014. EJurnal Medika Udayana.

Bell, J., Curtis, S. L. \& Alay $\tilde{A}^{3} n$, S. (2003) Trends in delivery care in six countries.

Brahim, R., Hasnawati, Anggraini, N. D. \& Ismandari, F. (2010) Demam Berdarah Dengue Di Indonesia Tahun 1968-2009. Buletin Jendela Epidemiologi, Vol 2(Agustus 2010): 1-15.

Budioro, B. (1998) Pendidikan Kesehatan Masyarakat . Semarang:Universitas Diponegoro.
Fathi, F., Keman, S. \& Wahyuni, C. U. (2005) Peran faktor lingkungan dan perilaku terhadap penularan demam berdarah dengue di Kota Mataram. Jurnal Kesehatan Lingkungan, 2(1).

Francisco, F., Kaunang, W. P. \& Kekenusa, J. S. (2018) Hubungan Antara Faktor Lingkungan Biologis Dengan Kejadian Penyakit Demam Berdarah Dengue (DBD) Di Wilayah Kerja Puskesmas Tikala Manado. Community Health, 2(5).

Gabrysch, S. \& Campbell, O. M. (2009) Still too far to walk: literature review of the determinants of delivery service use. BMC Pregnancy and Childbirth, 9(1): 1.

Green, L. W. \& Kreuter, M. W. (1991) Health promotion planning: an educational and environmental approach.

Hasyim, D. M. (2016) Faktor-faktor yang Berhubungan dengan Tindakan Pemberantasan Sarang Nyamuk Demam Berdarah Dengue (PSN DBD). Jurnal Kesehatan, 4(2).

Jamil, A. I. (2019) Kemenkes: Per 1 Februari 2019, Ada 15.132 Kasus DBD di Indonesia. INews.id. Jakarta.

Kemenkes RI (2011) Modul pengendalian demam berdarah dengue. Jakarta: Direktorat Jenderal Pengendalian Penyakit.

Kemenkes RI (2016a) Kendalikan DBD Dengan PSN 3M Plus. Jakarta: Kementrian Kesehatan Republik Indonesia, 1-2.

Kemenkes RI (2016b) Surat Edaran No. PM.01.11/MENKES/591/2016 Tentang Pelaksanaan Pemberantasan Sarang Nyamuk 3m Plus dengan Gerakan Satu Rumah Satu Jumantik. Jakarta: Kementerian Kesehatan RI.

Kepmenkes RI (1992) Keputusan Menteri Kesehatan Nomor 581/MENKES/SK/VII/1992 Tentang Pemberantasan Penyakit Demam Berdarah Dengue (DBD). Jakarta.

Koenraadt, C. J., Tuiten, W., Sithiprasasna, R., Kijchalao, U., Jones, J. W. \& Scott, T. W. (2006) Dengue knowledge and practices and their impact on Aedes aegypti populations in Kamphaeng Phet, Thailand. The American journal of tropical medicine and hygiene, 74(4): 692-700.

Maulida, I., Prastiwi, R. S. \& Hapsari, L. H. (2016) Analisis Hubungan Karakteristik Kepala Keluarga dengan Perilaku Pencegahan Demam Berdarah di Pakijangan Brebes. Jurnal INFOKES Universitas Duta Bangsa Surakarta, $6(1)$.

Monintja, T. C. (2015) Hubungan antara karakteristik individu, pengetahuan dan sikap dengan tindakan PSN DBD masyarakat Kelurahan Malalayang I Kecamatan Malalayang Kota Manado. Jikmu, 5(5).

Mudin, R. N. (2015) Dengue Incidence and the Prevention and Control Program in Malaysia. THE INTERNATIONAL MEDICAL JOURNAL MALAYSIA, Volume 14 Number 1, (June 2015).

Nadesul, H. (1998) 100 pertanyaan dan jawaban demam berdarah, Jakarta:Puspa Swara.

Notoatmodjo, S. (2003) Ilmu Kesehatan Masyarakat.

Notoatmodjo, S. (2010) Ilmu perilaku kesehatan. Jakarta: Rineka Cipta, 20026-35.

Ooi, E.-E., Goh, K.-T. \& Gubler, D. J. (2006) Dengue Prevention and 35 Years of Vector Control in 
Singapore. Emerging Infectious Diseases Vol. 12, No. 6, (June 2006): 887-893.

Prasetyani, R. D. (2015) Faktor-faktor yang berhubungan dengan kejadian demam berdarah dengue. Jurnal Majority, 4(7): 61-66.

Pusdatin Setjen Kemenkes RI (2015) Situasi DBD di Indonesia. IInfoDatin. Jakarta: Sekertariat Jendral Kemenkes RI.

Puskomblik Setjen Kementerian Kesehatan RI (2015) Demam Berdarah Biasanya Mulai Meningkat di Januari. [Accessed 12 Maret 2019].

Rezania, N. \& Handayani, O. W. K. (2015) Hubungan karakteristik individu dengan praktik kader jumantik dalam PSN DBD di Kelurahan Sampangan Semarang. Unnes Journal of Public Health, 4(1).

Supriyanto, H. \& Suharto, S. (2011) Hubungan Antara Pengetahuan, Sikap, Praktek Keluarga Tentang Pemberantasan Sarang Nyamuk (PSN) Dengan Kejadian Demam Berdarah Dengue di Wilayah Kerja Puskesmas Tlogosari Wetan Kota Semarang. Faculty of Medicine.

Suwanbamrung, C. (2012) Children's basic knowledge and activities for dengue problem solution: an islamic religious school, Southern Thailand. Asian Pacific Journal of Tropical Disease, 2(6): 456-464.
Thaddeus, S. \& Maine, D. (1994) Too far to walk: maternal mortality in context. Social science \& medicine, 38(8): 1091-1110.

Untoro, G. D. (1992) Pengaruh Pencahayaan Alamiah Pada Jumlah Produksi Telur Nyamuk Aedes Aegypti Sebagai Vektor Penyakit Demam Berdarah Dengue. Postgraduate, Diponegoro University.

Waluyo, B. \& Nurullita, U. (2011) Pengaruh Penggunaan Cahaya Buatan Terus Menerus Terhadap Perilaku Aedes aegypti Menghisap Darah. Jurnal Kesehatan Masyarakat Indonesia, 7(1).

WHO (2012) Global strategy for dengue prevention and control 2012-2020.

WHO (2018) WHO Fact sheet: Dengue and severe dengue. Available on: https://www.who.int/news-room/factsheets/detail/dengue-and-severe-dengue. $\quad 13$ September 2018 ed.: World Health Organization.

Wong, L. P., Shakir, S. M. M., Atefi, N. \& AbuBakar, S. (2015) Factors Affecting Dengue Prevention Practices: Nationwide Survey of the Malaysian Public. PLOS ONE 10(4)1-16.

Yatim, F. (2001) Macam macam Penyakit Menular dan Pencegahannya. Pusat Penelitian dan Pengembangan Penyakit Menular. 